\title{
Peningkatan Kemampuan Pemecahan Masalah dan Kemandirian Belajar Mahasiswa Melalui Pembelajaran Berbasis Masalah
}

\author{
Fitrianto Eko Subekti ${ }^{*}$, Akhmad Jazuli ${ }^{2}$ \\ 1,2Program Studi Pendidikan Matematika, Universitas Muhammadiyah Purwokerto, \\ Purwokerto, Indonesia; ${ }^{*}$ efitrians@gmail.com ${ }^{2}{ }^{2}$ khmadjazuli.ump@gmail.com ${ }^{2}$
}

Info Artikel: Dikirim: 19 Oktober 2019; Direvisi: 31 Januari 2020; Diterima: 5 Maret 2020 Cara sitasi: Subekti, F. E, \& Jazuli, A. (2020). Peningkatan Kemampuan Pemecahan Masalah dan Kemandirian Belajar Mahasiswa Melalui Pembelajaran Berbasis Masalah. JNPM (Jurnal Nasional Pendidikan Matematika), 4(1), 13-27.

\begin{abstract}
Abstrak. Penelitian ini merupakan penelitian tindakan kelas yang bertujuan untuk meningkatkan kemampuan pemecahan masalah dan kemandirian belajar mahasiswa melalui pembelajaran berbasis masalah. Subjek penelitian adalah mahasiswa program studi pendidikan matematika yang mengambil mata kuliah Aplikasi Komputer. Penelitian dilaksanakan dalam 3 siklus, dimana setiap siklus terdiri atas 2 pertemuan. Data diperoleh melalui tes kemampuan pemecahan masalah dan angket kemandirian belajar. Hasil tes pemecahan masalah dari siklus I sampai dengan siklus III selalu mengalami peningkatan. Rata-rata tes pemecahan masalah pada siklus I sebesar 71,58; pada siklus II sebesar 76,67; dan pada siklus III sebesar 81,88. Data kemandirian belajar yang diambil menggunakan angket menunjukkan terjadi peningkatan dari siklus I ke siklus berikutnya. Pada siklus I, rata-rata kemandirian belajar sebesar 60,53; pada siklus II sebesar 65,29; dan pada siklus III sebesar 68,12. Berdasarkan hasil tersebut dapat dikatakan bahwa penerapan pembelajaran berbasis masalah dapat meningkatkan kemampuan pemecahan masalah dan kemandirian belajar mahasiswa yang mengikuti mata kuliah aplikasi komputer.
\end{abstract}

Kata Kunci: Kemampuan Pemecahan Masalah, Kemandirian Belajar, Pembelajaran Berbasis Masalah.

Abstract. This research was action research which aimed to improve the problem solving skills and the self-directed learning using problem based learning. The subject of the research was the student at the programme of study in mathematics education who took Computer Application courses. This research was held in three cycles in with two meetings at each cycle. The data were taken through problem solving skills test and self-directed learning questionnaire. The problem solving test result from the first to the third cycle shown an increase. The average first cycle was 71,58, the second cycle was 76,67, and the third cycle was 81,88 . The result data of self-directed learning showed that there was an increase from the first cycle to the next cycle. In the first cycle, the average student's self-directed learning was 60,53, the second cycle was 65,29, and the third cycle was 68,12. Based on the result, it 
can be concluded that the application of Problem Based Learning could improve the problem solving skills and the self-directed learning of students who took the Computer Application courses.

Keywords: Problem Solving Skills, Self-Directed Learning, Problem Based Learning.

\section{Pendahuluan}

Suatu proses pembelajaran sebaiknya tidak hanya memfokuskan pada transformasi pengetahuan, akan tetapi melatih pola pikir mahasiswa dalam mentransformasi kemampuan yang dibutuhkan dalam kehidupan. Salah satu kemampuan yang dibutuhkan adalah kemampuan pemecahan masalah. Kemampuan pemecahan masalah sangat dibutuhkan terutama ketika menghadapi permasalahan yang sama dan membutuhkan solusi yang berkelanjutan (Chaudhry \& Rasool, 2012). Masalah dapat dikategorikan menjadi dua, yaitu: masalah rutin dan non rutin. Masalah dikatakan rutin jika metode penyelesainnya dapat ditentukan segera, sedangkan masalah dikatakan non rutin, jika masalah tersebut tidak hanya membutuhkan keterampilan prosedural, tetapi juga keterampilan dalam memutuskan metode penyelesaian masalah (Laterell, 2013).

Menurut Killen (1998) ada beberapa cara untuk mengembangkan keterampilan pemecahan masalah, yaitu: 1) doronglah peserta didik untuk membandingkan masalah yang sulit dengan permasalahan yang sama atau terkait; 2) kembangkan kemampuan mencari alternatif terhadap persoalan yang dihadapi; 3) kembangkan kemampuan memprediksi kemungkinan keberhasilan proses penyelesaian masalah yang dilakukan; 4) berlatih menyelesaikan persoalan dengan langkah-langkah yang digunakan dalam pemecahan masalah; 5) kembangkan kemampuan dalam menganalisis permasalahan; 6) jadikan persoalan sebagai cara untuk belajar menyelesaikan permasalahan; dan (7) perlu adanya kemauan dan ketekunan dalam menyelesaikan persoalan yang diberikan.

Kemampuan pemecahan masalah merupakan kemampuan seseorang dalam bereksplorasi dan memunculkan strategi yang kreatif untuk memperoleh pengetahuan sehingga menemukan solusi dari permasalahan yang dihadapi (Csapó \& Funke, 2017). Terdapat empat tahapan pemecahan masalah menurut Polya (1957), yaitu: memahami masalah, membuat rencana, melakukan penyelesaian masalah, dan melihat kembali hasil yang dikerjakan. Memahami masalah merupakan bagian penting dari proses penyelesaian masalah, karena dengan memahami masalah maka permasalahan yang muncul akan mudah teratasi (Özreçberoğlu \& Çağanağa, $\underline{2018)}$. 
Hal-hal yang dapat dilakukan pada saat memahami masalah adalah dengan cara menentukan apa yang diketahui dan yang tidak diketahui, apa yang ditanyakan, serta memprediksi kecukupan informasi yang diketahui untuk menyelesaikan permasalahan. Tahap merencanakan solusi dengan cara menemukan benang merah antara data yang diketahui dan tidak ketahui, serta mempertimbangkan masalah lain jika benang merah tidak langsung diketahui. Melaksanakan rencana solusi dan memeriksa setiap langkah yang dilakukan. Memeriksa solusi yang diperoleh dengan cara memeriksa hasilnya ataupun menyelesaikan dengan cara yang berbeda (Polya, 1957).

Selain kemampuan pemecahan masalah, kemandirian belajar dibutuhkan dalam kehidupan. Kemandirian belajar yang tinggi menjadi salah satu faktor yang mempengaruhi kemampuan pemecahan masalah (Lestari, Andinny \& Mailizar, 2019). Menurut Meyer, Haywood, Sachdev, \& Faraday (2008) kemandirian belajar dipengaruhi oleh faktor internal dan eksternal. Faktor internal terkait dengan aspek afektif berupa kemauan, motivasi dan emosi, serta aspek kognitif terkait dengan kemampuan dalam memfokuskan perhatian dalam proses pemecahan masalah. Sedangkan faktor eksternal terkait dengan keterampilan guru dalam menjalin hubungan dengan peserta didik dan dalam menciptakan lingkungan yang mendukung. Desmita (2009) menyatakan bahwa, ciri-ciri orang yang memiliki kemandirian belajar adalah sebagai berikut: (1) memiliki kemampuan dalam menentukan nasib sendiri; 2) kreatif dan inisiatif; 3) bertanggung jawab; 4) mampu menahan diri; 5) membuat keputusan sendiri; dan 6) mampu mengatasi masalah dengan kemampuan yang dimilikinya.

Mata kuliah aplikasi komputer merupakan mata kuliah pilihan yang bertujuan untuk membekali mahasiswa dalam mengolah, menyajikan data, memilih metode untuk menganalisis data menggunakan aplikasi software statistik, serta menginterpretasikan dan menarik kesimpulan berdasarkan hasil analisis data tersebut. Ketepatan dalam memilih metode statistik pada saat melaksanakan penelitian ilmiah memberikan jaminan kevalidan hasil pengolahan data dan dapat dipercaya secara ilmiah (Khusainova, Shilova, \& Curteva, 2016).

Berdasarkan pengalaman peneliti dalam mengajar mata kuliah aplikasi komputer ada beberapa persoalan yang muncul, diantaranya: 1) mahasiswa mampu menganalisis data secara parsial, tetapi kesulitan dalam menganalisis data secara keseluruhan; 2) mahasiswa kesulitan dalam menginterpretasikan dan memberikan kesimpulan atas hasil analisis data 
tersebut; 3) kurangnya kemampuan mahasiswa menerapkan memahami dan analisis olah data statistik dalam kasus-kasus penelitian pendidikan matematika; 4) mahasiswa hanya mengandalkan materi yang diberikan oleh dosen; 5) kurangnya kesadaran untuk mencari sumber-sumber pendukung materi pembelajaran; 6) kemampuan materi prasyarat yang tidak begitu baik; dan 7) masih banyak mahasiswa yang mengandalkan teman ketika menyelesaikan permasalahan. Hal ini sejalan dengan Batanero, Burrill, \& Reading (2011) yang menyatakan bahwa beberapa kesulitan yang dialami dalam belajar statistika inferensia, diantaranya: kesulitan dalam menentukan sampel, distribusi sampel, kesulitan dalam menginterpretasi data, kesulitan dalam menentukan hipotesis nol dan alternatif, serta kesulitan memahami antara nilai signifikan dan $p$-value.

Berdasarkan persoalan tersebut, diperlukan suatu pembelajaran yang dapat memberikan kesempatan pada mahasiswa untuk mentransformasikan keterampilan belajar dan mampu memecahkan persoalan yang diberikan. Salah satu pembelajaran yang diduga dapat mengembangkan kemampuan pemecahan masalah dan kemandirian belajar adalah Pembelajaran Berbasis Masalah/Problem Based Learning (PBL). PBL merupakan pembelajaran yang berfokus pada masalah otentik dan berpusat pada peserta didik (Marra, Jonassen, Palmer, \& Luft, 2014). PBL memberikan kesempatan pada peserta didik secara mandiri, baik individu maupun kelompok berusaha mendefinisikan dan menetapkan masalah, serta melakukan hipotesis penyelesaian masalah dan diakhiri dengan penyimpulan (Midla \& Coryell, 2010). Sedangkan menurut Cahyo (2013), PBL merupakan suatu pembelajaran yang menekankan pada prinsip penggunaan masalah sebagai titik awal untuk mendapatkan pengetahuan yang baru. Dengan demikian dapat dikatakan bahwa PBL merupakan pembelajaran yang diawali dengan masalah otentik untuk merangsang peserta didik dalam menyelesaikan masalah tersebut.

Lima karakteristik PBL, yaitu: berfokus pada masalah, berpusat pada peserta didik, mementingkan kemandirian belajar, reflektif, dan peran pendidik sebagai fasilitator (Marra, Jonassen, Palmer, \& Luft, 2014). Aktivitas PBL memberikan pengalaman kepada peserta didik untuk mencari solusi berdasarkan pengalaman dan pengetahuan yang dimiliki serta membangun pengetahuan baru berdasarkan penyelesaian yang telah dilakukan (Suprapto, Fahrizal, \& Priyono, 2017). Beberapa tahapan yang dilakukan dalam PBL, yaitu: identifikasi masalah, menetapkan masalah, brainstroming, menentukan solusi sementara, merumuskan tujuan, mengumpulkan informasi, dan berbagi hasil (Wood, 2003). Sedangkan tahapan menurut 
Arends (2012) meliputi: orientasi pada masalah, mengorganisasi peserta didik, investigasi mandiri (individu maupun kelompok), penyajian hasil, dan evaluasi hasil penyajian.

Berdasarkan permasalahan tersebut tujuan penelitian ini adalah untuk meningkatkan kemampuan pemecahan masalah matematis dan kemandirian belajar mahasiswa melalui PBL.

\section{Metode}

Penelitian ini merupakan penelitian tindakan yang bertujuan untuk meningkatkan kemampuan pemecahan masalah dan kemandirian belajar mahasiswa. Subjek penelitian adalah mahasiswa program studi pendidikan matematika Universitas Muhammadiyah Purwokerto yang mengambil mata kuliah Aplikasi Komputer sebanyak 30 mahasiswa. Adapun jadwal pelaksanaan tindakan dan pembagian materi disajikan pada Tabel 1.

Tabel 1. Jadwal Pelaksanaan Tindakan

\begin{tabular}{cccl}
\hline No & Siklus & Tanggal Pelaksanaan & \multicolumn{1}{c}{ Materi } \\
\hline 1 & I & 10 April 2019 & Uji Homogenitas Data \\
2 & I & 13 April 2019 & Uji Korelasi Data \\
3 & II & 20 April 2019 & Uji Regresi Linier \\
4 & II & 24 April 2019 & Uji Banding Satu Sampel \\
5 & III & 27 April 2019 & Uji Banding Dua Sampel Independen \\
6 & III & 4 Mei 2019 & Uji Banding Dua Sampel Berpasangan \\
\hline
\end{tabular}

Data kemampuan pemecahan masalah diperoleh menggunakan tes, sedangkan data kemandirian belajar diperoleh dengan menggunakan angket. Penelitian dilaksanakan dalam 3 siklus, dimana setiap siklusnya terdiri atas 2 pertemuan. Setiap siklus diawali dengan perencanaan, dilanjutkan dengan pelaksanaan tindakan, observasi dan evaluasi, serta refleksi.

Pada tahap perencanan untuk setiap siklusnya dihasilkan: 1) Satuan Acara Perkuliahan (SAP); 2) Lembar Kerja Mahasiswa (LKM); 3) handout; 4) tes akhir siklus; dan 5) angket kemandirian belajar mahasiswa. Setelah dihasilkan perangkat pembelajaran dan instrumen penelitian untuk siklus I, kemudian sesuai jadwal yang telah ditentukan dilaksanakan pelaksanaan tindakan, dilanjutkan observasi dan evaluasi, serta refleksi. Pelaksanaan tindakan menggunakan model PBL. Disetiap akhir siklus mahasiswa diberikan tes kemampuan pemecahan masalah dan mengisi angket kemandirian belajar. 
Tes kemampuan pemecahan masalah menggunakan 4 langkah, yaitu: 1) memahami masalah; 2) merencanakan penyelesaian masalah; 3) melaksanakan penyelesaian masalah; dan 4) penyimpulan. Setelah data diperoleh, kemudian disajikan dan dianalisis secara kuantitatif untuk setiap siklusnya. Data disajikan dalam bentuk tabel maupun diagram.

\section{Hasil dan Pembahasan}

Hasil tes kemampuan pemecahan masalah per langkah untuk setiap siklus disajikan pada Tabel 2.

Tabel 2. Rata-rata Kemampuan Pemecahan Masalah per Langkah

\begin{tabular}{ccccc}
\hline Langkah & Skor max. & Siklus 1 & Siklus 2 & Siklus 3 \\
\hline 1 & 2 & 1,84 & 1,89 & 2,00 \\
2 & 3 & 2,26 & 2,56 & 2,75 \\
3 & 3 & 2,26 & 2,39 & 2,44 \\
4 & 2 & 0,79 & 0,83 & 1,00 \\
\hline
\end{tabular}

Hasil tersebut dapat disajikan dalam bentuk diagram batang pada Gambar 1.

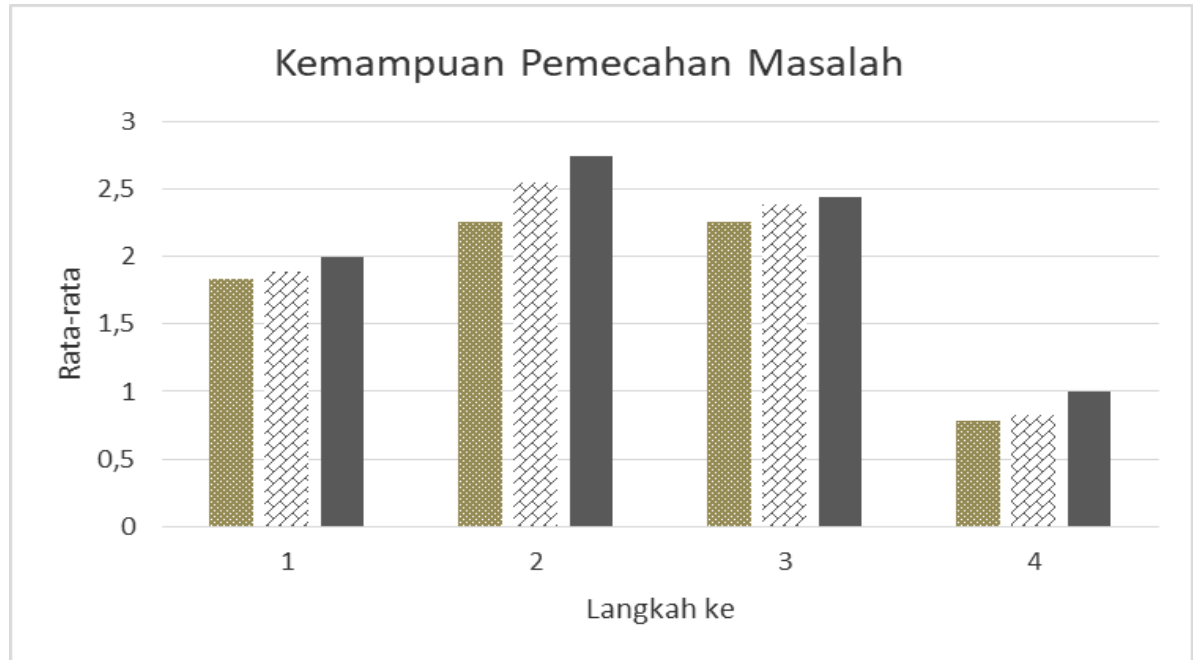

Gambar 1. Rata-rata Kemampuan Pemecahan Masalah per Langkah

Tabel 2 dan Gambar 1 menunjukan bahwa untuk setiap langkah pemecahan masalah dari siklus 1 ke siklus berikutnya selalu mengalami peningkatan. Secara umum hasil cukup memuaskan, terutama pada langkah memahami masalah, merencanakan penyelesaian masalah dan melaksanakan penyelesaian masalah. Berikut beberapa kesalahan yang dilakukan oleh mahasiswa, yaitu: 1) kesalahan dalam merumuskan hipotesis penelitian; 2) kurang teliti pada saat menginputkan data; 3) salah memahami permasalahan sehingga salah dalam merencanakan penyelesaian masalah; 4) beberapa mahasiswa kurang konsisten dalam menggunakan simbol dalam 
hipotesis penelitian; dan 5) penyimpulan hasil analisis data yang kurang tepat (belum menjawab hipotesis penelitian).

Sedangkan data kemandirian belajar mahasiswa diperoleh menggunakan angket yang terdiri atas 8 indikator dengan 20 pertanyaan. Angket yang dikembangkan menggunakan angket tertutup skala Linkert dengan 5 alternatif pilihan jawaban. Indikator-indikator kemandirian belajar yang digunakan oleh peneliti adalah sebagai berikut: 1) berinisiatif; 2) merancang kebutuhan belajar; 3) menetapkan tujuan; 4) menetapkan strategi; 5) menganggap kesulitan sebagai tantangan; 6) mencari dan memanfaatkan sumber belajar yang dibutuhkan; 7) mengontrol proses dan mengevaluasi hasil belajar; dan 8) kemampuan mengatur diri sendiri. Adapun hasilnya dapat disajikan dalam Tabel 3.

Tabel 3. Rata-rata Kemandirian Belajar per Indikator

\begin{tabular}{ccccccccc}
\hline Siklus & \multicolumn{7}{c}{ Indikator ke- } \\
& 1 & 2 & 3 & 4 & 5 & 6 & 7 & 8 \\
\hline 1 & 2,89 & 3,26 & 3,26 & 3,30 & 3,16 & 3,19 & 3,32 & 3,35 \\
2 & 3,14 & 3,31 & 3,11 & 3,43 & 3,03 & 3,24 & 3,34 & 3,43 \\
3 & 3,15 & 3,53 & 3,33 & 3,53 & 3,24 & 3,47 & 3,41 & 3,49 \\
\hline
\end{tabular}

Hasil tersebut dapat disajikan dalam diagram batang pada Gambar 2.

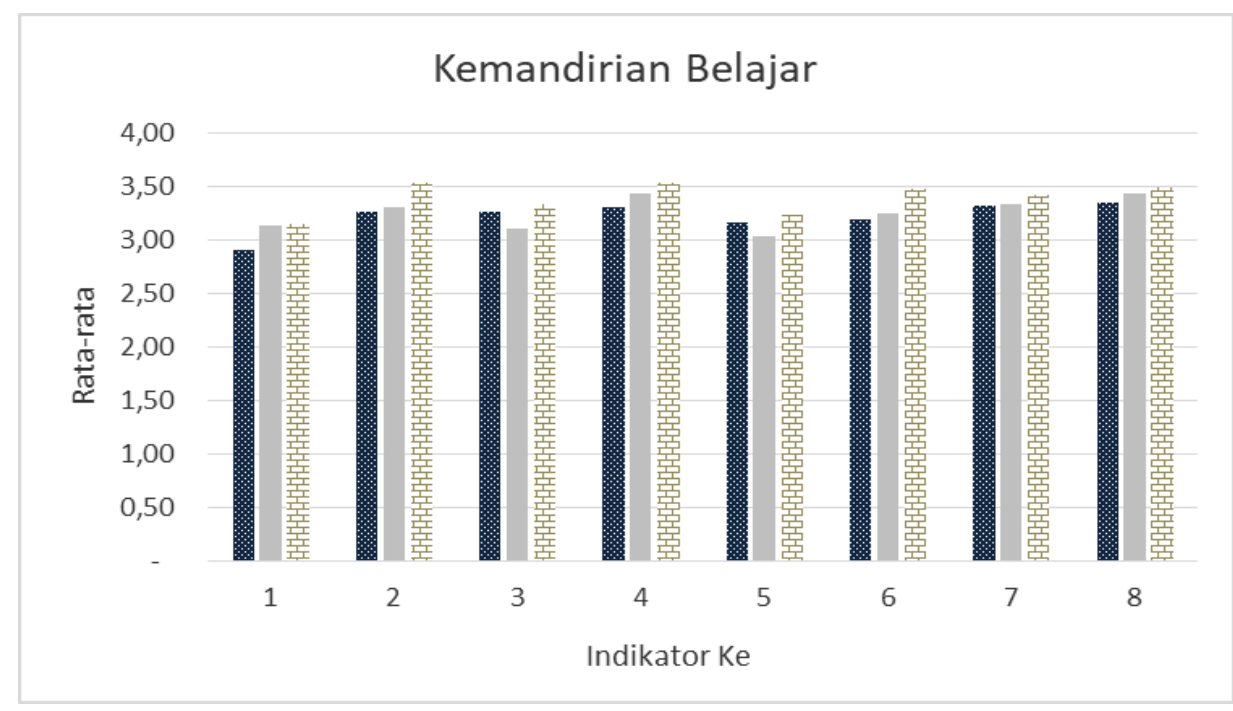

Gambar 2. Rata-rata kemadirian belajar per indicator

Tabel 3 dan Gambar 2 menunjukan bahwa sebagian besar indikator mengalami peningkatan dari siklus 1 ke siklus berikutnya. Hasil ini cukup memuaskan karena mayoritas rata-rata kemandirian belajar lebih besar dari 3,00 . 
Hasil tes kemampuan pemecahan masalah dan kemandirian belajar tersebut tidak terlepas dari aktivitas pembelajaran yang dilakukan. Peran pendidik sebagai fasilitator dan kolabolator memperkuat keberhasilan penerapan PBL (Choo, Rotgans, Yew, \& Schmidt, 2011). Berikut gambaran aktivitas pembelajaran setiap siklusnya.

\section{Deskripsi hasil pelaksanaan tindakan siklus I}

Pelaksanaan tindakan pada siklus I terdiri atas dua pertemuan. Pertemuan pertama membahas tentang uji homogenitas data berbantuan SPSS, sedangkan pada pertemuan 2 dibahas tentang materi uji korelasi data berbantuan SPSS. Sebelum pertemuan, handout materi dikirimkan melalui grup WhatsApp. Keuntungan penggunaan grup WhatsApp sebagai sarana pemberian informasi, menjadikan informasi dapat diberikan kapan saja dan dimana saja. Media sosial memberikan fasilitas yang dibutuhkan dalam pendidikan (Rajesh, Sreeja, \& Michael, 2015). Hal ini sejalan dengan pendapat dari Vervaart (2012) yang menyatakan bahwa internet dalam pendidikan memungkinkan seorang pendidik mendesain pembelajaran yang menarik, dimana dan kapan saja informasi dibutuhkan dapat diberikan. Hanya saja penggunaan media sosial dapat mempengaruhi spiritual maupun akademik baik secara positif maupun negatif (Talaue, AlSaad, AlRushaidan, AlHugail, \& AlFahhad, 2018).

Pemberian handout bertujuan agar mahasiswa memiliki gambaran awal tentang materi yang akan dibahas dan lebih siap ketika mengikuti pembelajaran. Selain itu, harapannya mahasiswa terbiasa untuk membaca, mencari sumber-sumber alternatif untuk melengkapi materi yang akan dipelajari. Pemberian handout ini merupakan salah satu bentuk pemberian scaffolding baik konseptual maupun prosedural (Phumeechanya \& Wannapiroon, 2014).

Pada saat pembelajaran tentang uji homogenitas data, diawali dengan mengingatkan kembali tentang materi uji normalitas data berbantuan SPSS, kemudian dilanjutkan dengan pemberian beberapa pertanyaan pancingan untuk menggali kemampuan dasar yang dimiliki terkait tentang uji homogenitas yang telah mereka pelajari pada mata kuliah sebelumnya. Sebagian besar mahasiswa mengaku kesulitan dalam memahami, kapan dan mengapa perlu dilakukan uji homogenitas data. Berdasarkan temuan awal tersebut, kemudian disajikan permasalahan yang terkait penggunaan uji homogenitas dalam penelitian pendidikan, terutama dalam penelitian eksperimen. Selain permasalahan ditampilkan dengan menggunakan layar LCD, permasalahan juga ada dalam LKM tentang uji homogenitas data. 
Dari permasalahan tersebut, mahasiswa diarahkan untuk dapat memahami kapan dan mengapa dilakukan uji homogenitas data. Selanjutnya dengan menggunakan persoalan yang ada dalam LKM, mahasiswa melakukan uji homogenitas berbantuan SPSS. Mahasiswa cenderung selalu melihat handout yang diberikan ketika menyelesaikan permasalahan yang diberikan. Setelah mengerjakan LKM, beberapa mahasiswa mempresentasikan hasil pekerjaannya di depan setelah ditunjuk. Beberapa kesalahan yang muncul, diantaranya: a) beberapa mahasiswa masih salah dalam menuliskan simbol pada hipotesis penelitian, b) hanya memindahkan tabel yang ada dalam output SPSS, dan 3) masih kurang teliti dalam menginputkan data.

Pada pertemuan kedua diawali dengan menggali kemampuan awal tentang materi uji korelasi. Kemampuan awal mahasiswa digali dengan bantuan media tentang diagram plot. Berdasarkan diagram plot, mahasiswa diarahkan mengingat kembali tentang kekuatan dan arah hubungan dari uji korelasi. Selanjutnya diberikan permasalahan yang terkait tentang aplikasi uji korelasi dalam penelitian pendidikan, dan dilanjutkan dengan presentasi hasil setelah ditunjuk terlebih dahulu.

Berdasarkan hasil observasi selama pembelajaran pada siklus I, terlihat bahwa mahasiswa masih mengandalkan handout yang diberikan oleh dosen, tanpa mencari sumber-sumber lain yang relevan. Mahasiswa masih terlihat ragu-ragu dalam menyelesaikan permasalahan yang diberikan dan masih kurang percaya diri ketika akan mempresentasikan hasilnya. Sedangkan berdasarkan hasil tes siklus I diperoleh rata-rata sebesar 71,58, dan rata-rata untuk angket kemandirian belajar sebesar 60,53. Terkait hasil ini maka perlu adanya perbaikan dalam merencanakan pembelajaran pada siklus II, dimana salah satu poin perbaikannya adalah memotivasi mahasiswa untuk tidak hanya mengandalkan materi dari handout yang diberikan, akan tetapi juga dengan mencari sumber-sumber lain yang relevan.

\section{Deskripsi hasil pelaksanaan tindakan siklus II}

Pada pertemuan 1, beberapa mahasiswa sudah membaca literatur yang dikirimkan lewat grup, hanya saja masih belum mencari literatur lain yang mendukung materi tersebut. Selain itu mahasiswa masih terlihat kebingungan membedakan kapan menggunakan uji korelasi dan kapan menggunakan uji regresi. Pertemuan ini difokuskan pada uji regresi linier sederhana dan ganda. Proses pembelajaran hampir sama dengan pertemuan sebelumnya. Beberapa mahasiswa masih salah dalam menuliskan persamaan regresi, membedakan penggunaan simbol $y$ dengan $\hat{y}$, serta masih kurang 
lengkap dalam memberikan kesimpulan berdasarkan hasil uji regresi yang dilakukan. Kesalahan juga masih terjadi dalam menuliskan simbol hipotesis antara regresi linier sederhana dengan uji regresi linier ganda.

Sedangkan pertemuan kedua dengan materi uji banding satu sampel diawali dengan mengingat kembali esensi tentang penggunaan uji banding dalam penelitian. Mahasiswa paham ada berbagai jenis uji banding, hanya saja masih terlihat bingung tentang aplikasi uji banding dalam penelitian pendidikan. Hal ini terlihat ketika diberikan permasalahan tentang uji banding satu sampel, mereka bingung untuk menyelesaikan permasalahan tersebut.

Berdasarkan permasalahan tersebut, mahasiswa diajak untuk memahami esensi dari uji banding satu sampel melalui permasalahan terkait aplikasi uji banding satu sampel dalam penelitian pendidikan. Setelah mengerjakan, beberapa mahasiswa mempresentasikan hasilnya di depan tanpa ditunjuk terlebih dahulu. Kebiasaan sebelumnya yang selalu melihat handout pada saat mengerjakan LKM, mulai jarang terlihat. Selama pembelajaran, mahasiswa terlihat mulai terbiasa dalam menyelesaikan permasalahan yang terkait aplikasi uji analisis data dalam penelitian pendidikan. Hanya saja masih ada beberapa mahasiswa yang masih hanya mengandalkan handout materi yang dikirim lewat grup WhatsApp.

Hasil tes pada siklus II diperoleh rata-rata sebesar 76,67, sedangkan rata-rata hasil angket kemandirian belajar adalah sebesar 65,29. Berdasarkan hasil tersebut, terlihat adanya peningkatan kemampuan pemecahan masalah dan kemandirian belajar mahasiswa dari siklus I ke siklus II. Walaupun demikian ada beberapa yang perlu menjadi perhatian, diantaranya adalah kesadaran mahasiswa dalam mencari berbagai sumber, perlu ditambah lagi contoh kasus dalam penelitian pendidikan, dan berikanlah tugas terstruktur terkait materi yang dipelajari. Pemberian tugas terstruktur merupakan salah satu bentuk dorongan agar kemandirian belajar mahasiswa terbentuk. Hal ini sejalan dengan pernyataan dari Bidokht \& Assareh (2011), bahwa kemandirian belajar dapat terbentuk melalui pemberian tugas-tugas baik dalam pembelajaran tatap muka ataupun penugasan lewat jaringan.

\section{Deskripsi hasil pelaksanaan tindakan siklus III}

Pada siklus III mahasiswa terlihat lebih siap dan semangat mengikuti pembelajaran. Walaupun demikian, beberapa kesalahan masih ditemukan, diantaranya: kesalahan dalam menggunakan uji satu atau dua pihak. Kesalahan ini berakibat menjadi pengujian kriteria menjadi salah. 
Mahasiswa sudah mulai terbiasa dalam menyelesaikan aplikasi tentang uji banding dua sampel berbantuan SPSS. Mereka terlihat sudah paham, kapan menggunakan uji banding dua sampel independen maupun dua sampel berpasangan. Di akhir pertemuan diberikan tes akhir siklus dan pengisian angket kemandirian belajar. Adapun hasil tes siklus III dengan rata-rata sebesar 81,88, dan rata-rata kemandirian belajar sebesar 68,12.

Hasil tes kemampuan pemecahan masalah dari siklus I sampai dengan siklus III disajikan pada Tabel 4.

Tabel 4. Rata-rata Kemampuan Pemecahan Masalah

\begin{tabular}{cc}
\hline Siklus & Rata-rata \\
\hline I & 71,58 \\
II & 76,67 \\
III & 81,88 \\
\hline
\end{tabular}

Dan disajikan dalam bentuk diagram garis pada gambar 3.

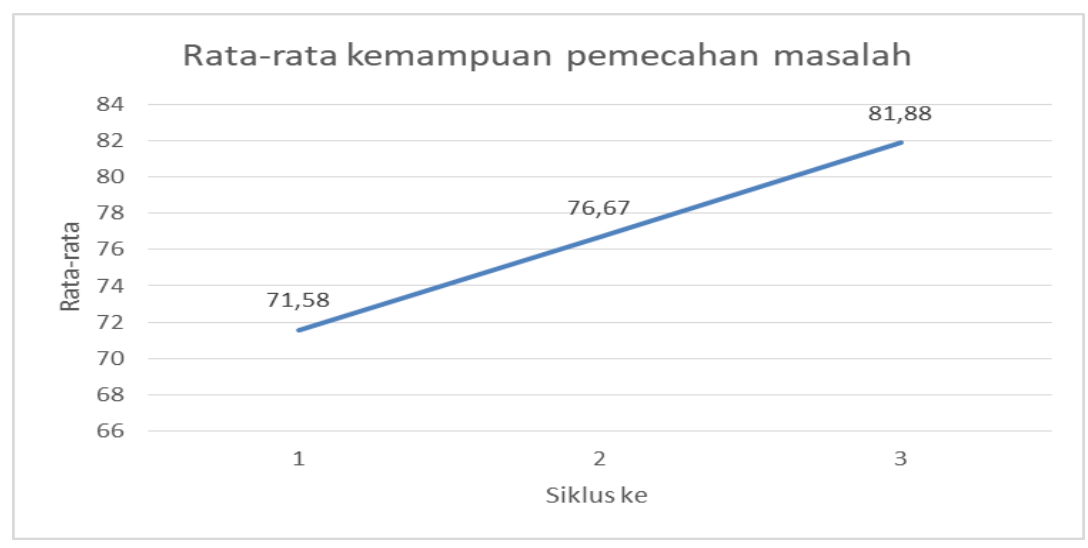

Gambar 3. Rata-rata Tes Kemampuan Pemecahan Masalah tiap Siklus

Sedangkan rata-rata kemandirian belajar mahasiswa disajikan pada tabel 5 .

Tabel 5. Rata-rata Kemandirian Belajar Mahasiswa

\begin{tabular}{cc}
\hline Siklus & Rata-rata \\
\hline I & 60,53 \\
II & 65,29 \\
III & 68,12 \\
\hline
\end{tabular}

Tabel 4, Tabel 5, serta diagram garis pada Gambar 3 dan Gambar 4 menunjukan bahwa terjadi peningkatan kemampuan pemecahan masalah dan kemandirian belajar mahasiswa dari siklus I sampai dengan siklus III. Peningkatan didukung dengan adanya peningkatan aktivitas mahasiswa yang semakin baik. 


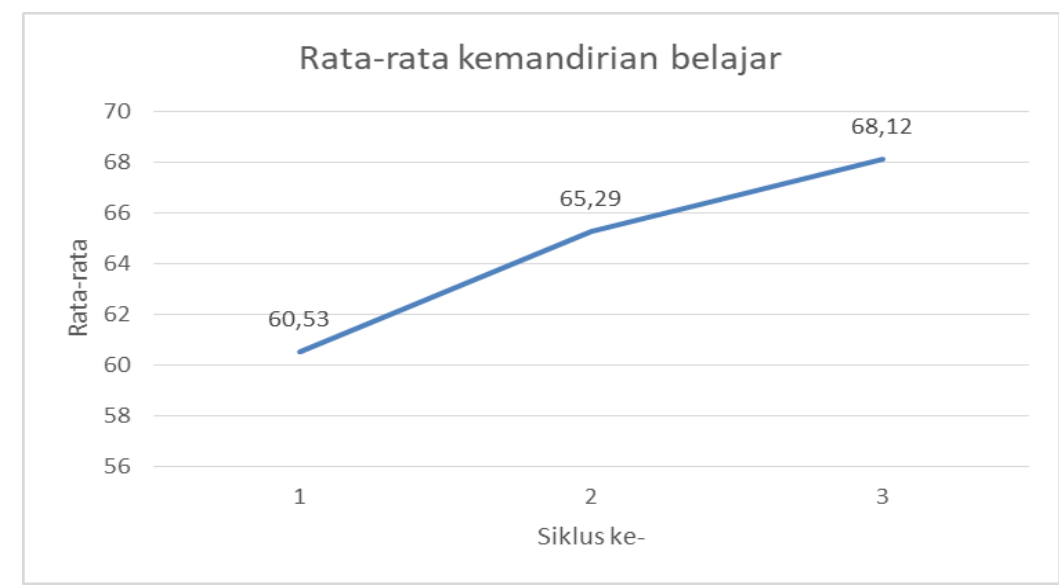

Gambar 4. Rata-rata kemandirian belajar mahasiswa

Pada siklus I mahasiswa masih terlihat ragu-ragu dalam menyelesaikan permasalahan. Hal ini ditunjukkan dengan mahasiswa masih sering melihat contoh pada handout materi yang telah diberikan disaat menyelesaikan permasalahan. Mahasiswa juga masih terlihat belum terbiasa mencari sumber-sumber lain untuk melengkapi materi yang ada dihandout. Selain itu disaat mahasiswa diberikan kesempatan untuk presentasi, mahasiswa presentasi bukan karena kemauan sendiri, tetapi setelah ditunjuk oleh dosen.

Peningkatan aktivitas terjadi pada siklus II, dimana pada siklus II beberapa mahasiswa berinisiatif mencari sumber lain. Mahasiswa mulai terbiasa menyelesaikan permasalahan terkait aplikasi dalam penelitian pendidikan terutama dalam penelitian eksperimen. Sedangkan pada siklus III, mahasiswa semakin percaya diri dalam menyelesaikan permasalahan dan mayoritas sudah tidak hanya mengandalkan handout yang diberikan dosen, tetapi sudah menggunakan sumber lain yang relevan. Berdasarkan pelaksanaan pembelajaran yang telah dilakukan terlihat bahwa mahasiswa semakin berani untuk mengungkapkan pendapatnya dan semakin baik kemampuan pemecahan masalahnya yang pada awalnya mereka kesulitan dalam menginterpretasikan data untuk menarik suatu kesimpulan dikarenakan sebagian besar mahasiswa lupa konsep statistika inferensia yang akan digunakan dalam mata kuliah ini.

Melalui pemberian motivasi dan scaffolding aktivitas pembelajaran menjadi semakin baik. Scaffolding membantu mahasiswa dalam proses mengklarifikasi konsep yang digunakan untuk menyelesaikan permasalahan (Aslam, Khanam, Fatima, Akbar, \& Muhammad, 2017). Selain itu pemahaman mahasiswa terkait metode statistik yang semakin baik menjadikan kemampuan pemecahan masalah mahasiswa semakin 
meningkat. Pengetahuan statistik yang baik dan penggunaan metode statistik yang tepat merupakan dasar untuk mendesain penelitian yang berkualitas, sebaliknya penggunaan metode yang tidak tepat dapat menyebabkan kesalahan dalam penyimpulan (Ali \& Bhaskar, 2016). Pemahaman konseptual dan penalaran statistik menjadi kunci keberhasilan dalam mempelajari statistik penelitian dan aplikasi yang lainnya (Guoqi, $\underline{2011)}$.

Hal ini sejalan dengan hasil penelitian yang dilakukan oleh Kadir, Abdullah, Anthony, Salleh, \& Kamarulzaman (2016) bahwa kemampuan pemecahan masalah yang menggunakan PBL lebih baik dibandingkan yang diajar menggunakan pembelajaran konvensional. Selain itu dari segi akurasi dan kualitas jawabannya juga lebih baik dibandingkan mahasiswa yang diajar menggunakan pembelajaran konvensional. Begitu juga dengan hasil penelitian yang lainnya menyatakan bahwa kemampuan pemecahan masalah yang mengikuti PBL lebih baik (Sariningsih \& Purwasih, 2017) dan lebih efektif dalam meningkatkan HOTS (Jailani, Sugiman, \& Apino, 2017) dari pada yang mengikuti pembelajaran ekspositori.

\section{Simpulan}

Berdasarkan hasil dan pembahasan di atas dapat disimpulkan bahwa PBL dapat meningkatkan kemampuan pemecahan masalah dan kemandirian belajar mahasiswa matematika pada mata kuliah Aplikasi Komputer. Kemampuan pemecahan masalah dan kemandirian belajar perlu menjadi prioritas, salah satu yang dapat dilakukan untuk penelitian selanjutnya adalah dengan pembelajaran berbasis proyek. Sehingga mahasiswa mampu merencanakan, melaksanakan, dan melaporkan hasil proyeknya.

\section{Daftar Pustaka}

Ali, Z., \& Bhaskar, S. B. (2016). Basic Statistical Tools in Research and Data Analysis. Indian Journal of Anaesthesia, 60(9), 662-669.

Arends, R.I. (2012). Learning to Teach Ninty Edition. Mc Graw Hill. New York.

Aslam, N., Khanam, A., Fatima, H. G., Akbar, H., \& Muhammad, N. (2017). Study of The Impact of Scaffold Instructions on The Learning Achievements of Post-Graduate Students. Journal of Arts and Social Sciences, 4(1), 71-78.

Batanero, C., Burrill, G., \& Reading, C. (2011). Teaching Statistics in School MathematicsChallenges for Teaching and Teacher Education. Teaching Statistics in School Mathematics Challenges for Teaching and Teacher Education A Joint ICMIIASE Study, 14(1), $41-45$.

Bidokht, M. H., \& Assareh, A. (2011). Life-long learners through problem-based and self directed learning. Procedia Computer Science, 3, 1446-1453.

Cahyo, A. (2013). Panduan Aplikasi Teori-teori Belajar Mengajar Teraktual dan Terpopuler. Diva Press. Yogyakarta. 
Choo, S. S. Y., Rotgans, J. I., Yew, E. H. J., \& Schmidt, H. G. (2011). Effect of worksheet scaffolds on student learning in problem-based learning. Advances in Health Sciences Education, 16(4), 517-528.

Csapó, B., \& Funke, J. (2017). The nature of problem solving. Using research to inspire 21st century learning.

Chaudhry, N. G., \& Rasool, G. (2012). A Case Study on Improving Problem Solving Skills of Undergraduate Computer Science Students. World Applied Sciences Journal, 20(1), 3439.

Desmita. (2009). Psikologi Perkembangan Peserta Didik. Bandung: PT Remaja Rosdakarya.

Guoqi, Q. (2011). Teaching, Learning and Retention of Statistical Ideas in Introductory Statistics Education. European Journal of Pure \& Applied Mathematics, 4(2), 103-116.

Jailani, J., Sugiman, S., \& Apino, E. (2017). Implementing The Problem-Based Learning In Order to Improve The Students' HOTS and Characters. Jurnal Riset Pendidikan Matematika, 4(2), 247-259.

Kadir, Z. A., Abdullah, N. H., Anthony, E., Salleh, B. M., \& Kamarulzaman, R. (2016). Does Problem-Based Learning Improve Problem Solving Skills?-A Study among Business Undergraduates at Malaysian Premier Technical University. International Education Studies, 9(5), 166.

Killen, R. (1998). Effective Teaching Strategies Lessons from Reseasrch and Practice. Australia: Social Science Press.

Khusainova, R. M., Shilova, Z. V., \& Curteva, O. V. (2016). Selection of Appropriate Statistical Methods for Research Results Processing. Mathematics Education, 11(1), 303315.

Laterell, C. M. (2013). What Is Problem-solving Ability? LATM Journal, 1(1), 1-12.

Lestari, I., Andinny, Y., \& Mailizar, M. (2019). Pengaruh Model Pembelajaran Situation Based Learning dan Kemandirian Belajar Terhadap Kemampuan Pemecahan Masalah Matematis. JNPM (Jurnal Nasional Pendidikan Matematika), 3(1), 95-108.

Marra, R., Jonassen, D., Palmer, B., \& Luft, S. (2014). Why Problem-Based Learning Works: Theoretical Foundations. Journal on Excellence in College Teaching, 25, 221-238.

Meyer, B., Haywood, N., Sachdev, D., \& Faraday, S. (2008). What is independent learning and what are the benefits for students? How is independent learning viewed by teachers? London: Department for Children, Schools and Families Research Report, 51, 1-6.

Midla, G. S., \& Coryell, J. E. (2010). Problem-based learning preparation for physician assistant faculty. U.S. Army Medical Department Journal, 39-47.

Özreçberoğlu, N., \& Çağanağa, Ç. K. (2018). Making It Count: Strategies for Improving Problem-Solving Skills in Mathematics for Students and Teachers' Classroom Management. Eurasia Journal of Mathematics, Science and Technology Education, 14(4), 1253-1261.

Phumeechanya, N., \& Wannapiroon, P. (2014). Design of Problem-based with Scaffolding Learning Activities in Ubiquitous Learning Environment to Develop Problem-solving Skills. Procedia - Social and Behavioral Sciences, 116, 4803-4808.

Polya, G. (1957). How to Solve it. Princenton University Press. United States of America.

Rajesh, Sreeja, \& Michael, J. (2015). Effectiveness of Social Media in Education. International Journal of Innovative Research in Advanced Engineering, 10(2), 2349-2163.

Sariningsih, R., Purwasih, R. 2017. Pembelajaran Problem Based Learning untuk Meningkatkan Kemampuan Pemecahan Masalah Matematis dan Self Efficacy Mahasiswa Calon Guru. JNPM (Jurnal Nasional Pendidikan Matematika), 1(1), 163-177. 
Suprapto, E., Fahrizal, F., Priyono, P., \& K., B. (2017). The Application of Problem-Based Learning Strategy to Increase High Order Thinking Skills of Senior Vocational School Students. International Education Studies, 10(6), 123-129.

Talaue, G. M., AlSaad, A., AlRushaidan, N., AlHugail, A., \& AlFahhad, S. (2018). The Impact of Social Media on Academic Performance of Selected College Students. International Journal of Advanced Information Technology, 8(4), 27-35.

Vervaart, P. (2012). Role of Social Media and the Internet in Education. Ejifcc, 23(2), 24-247.

Wood, D. F. (2003). Problem Based Learning What Is Problem Based Learning? BMJ, 326(2), 328-330. 